\title{
Cutaneous Melanoma pT1a TNM Finding v6
}

National Cancer Institute

\section{Source}

National Cancer Institute. Cutaneous Melanoma pT 1a TNM Finding v6. NCI Thesaurus.

Code C48843.

Cutaneous melanoma 1.0mm or less in thickness and Clark level II or III, with no ulceration. (from AJCC 6th Ed.) 